men man aner to linjer: for det første dyktige bakspillere som kunne kunsten å fiske i opprørt vann, dvs. fremme overraskende forslag på rett tidspunkt, og for det andre en klar, men initialt godt skjult målsetting om å vokse til å bli noe mer enn en skole for feltskjærere. Her kom instituttets første professor i kjemi, Jöns Jacob Berzelius (1779-1848), til å spille en meget fremtredende rolle. Han la grunnlaget for den naturvitenskapelige utdanningen i medisin, noe som senere alltid har preget Karolinska Institutet. Det førte bl.a. til at Alfred Nobel (1833-96) valgte gjøkungen til å dele ut nobelprisen i fysiologi eller medisin, og har også ført til at Karolinska Institutet har flere nobelpriser enn samtlige andre medisinske fakulteter i Skandinavia til sammen. Det kan med trygg forvissning «trona på minnen från fornstore dar», og vi andre kan håpe at det vil bli «vad Du var».

\section{Afasi for logopeder og andre}

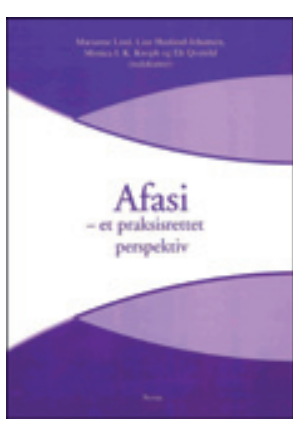

Marianne Lind, Line Haaland-Johansen, Monica I. K. Knoph et al, red.

Afasi

Et praksisrettet perspektiv. 240 s, tab, ill. Oslo: Novus forlag, 2010. Pris NOK 295 ISBN 978-82-7099-594-3

Til tross for at språkvansker etter hjerneskade har interessert mange leger og helsepersonell i lang tid, er afasi et lite pløyd akademisk felt i Norge. Etter psykolog Ivar Reinvangs banebrytende arbeider i 1970- og 80-årene, som bl.a. resulterte i Norsk grunntest for afasi (1), har det inntil nylig vært heller stille fra behandlerne. Språkvitere som Inger Moen, Helene Uri og Marianne Lind har stått for det meste av norsk afasiforskning.

På bakgrunn av den heller sparsomme forskningen på afasirehabilitering i Norge, har redaktørene som mål å dokumentere den logopediske virksomheten i Norge per i dag. Det er denne logopedivirksomheten som menes med «praksis» i undertittelen; man burde kanskje funnet plass til ordet «logopedi» i tittelen. Boken har sitt utspring i Afasiforum, et nasjonalt faglig nettverk av logopeder fra ulike institusjoner innenfor afasiomsorgen. Logopeder og logopedstudenter er angitt som primær målgruppe.

Boken inneholder 15 kapitler, hvorav forfatterne i de sju første, ut fra et teoretisk perspektiv, tar opp temaene afasirehabilitering, kartlegging og dokumentasjon, barn hhv. eldre med afasi, tospråklighet, gruppebehandling og hjelpemidler. De resterende åtte kapitlene er kasusbeskrivelser med vekt på ulike logopediske terapiformer. I sum gir de dermed en flerfasettert oversikt over hvordan afasilogopedi utøves i praksis, og hvilke teoretiske forankringer som ligger til grunn.

Det er noe uklart for meg om redaktørene ser for seg at leserne studerer boken fra a til å, eller at de leser utvalgte kapitler. Hvis sistnevnte var målet, burde kapitlene inneholde tydeligere sammendrag. Uansett kunne boken med fordel vært noe strammere redigert. Det er eksempelvis overflødig å lese for femte gang at afasi kan føre til vansker med både språkforståelse og produksjon, noe som flertallet av leserne antakelig vet uansett.

Det er en del forskjeller i hvor vitenskapelig anlagt kapitlene er, både med tanke på oppbygging, referansebruk og språklig presisjonsnivå. Videre ville boken profitert på flere figurer, bilder og tabeller for å understreke og anskueliggjøre budskapet i de enkelte kapitlene.
Redaktørene har lyktes godt med sin viktigste oppgave, nemlig å gi en god, første oversikt over afasilogopedisk praksis i Norge. Jeg vil anta at boken vil bli pensum for logopedstudenter og at mange logopeder vil finne den nyttig for å oppdatere seg og for å evaluere egen virksomhet. For andre som er interessert $i$ afasi, og som kanskje lurer på «hva logopedene egentlig driver med», vil boken gi en kortfattet og lettlest oversikt over dagens språkterapeutiske praksis.

\section{Frank Becker}

Sunnaas sykehus

\section{Litteratur}

1. Reinvang I, Engvik H. Norsk grunntest for afasi: håndbok. Oslo: Universitetsforlaget, 1980.

\section{God og kortfattet oversikt om diabetes}

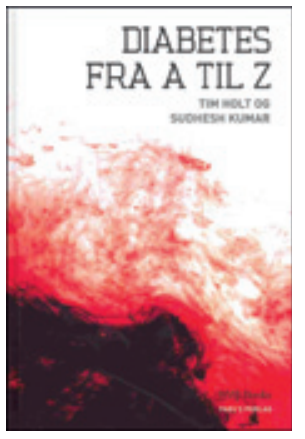

Tim Holt, Sudhesh Kumar
Diabetes fra A til Z

149 s, tab, ill. København: FADL's forlag, 2010. Pris DKK 300

ISBN 978-87-7749-554-0

Denne nyttige boken er en oversettelse av den engelske $A B C$ of diabetes. Den danske tittelen er kanskje litt uheldig, idet det lett kan oppfattes som en fullstendig innføring i alt om diabetes, mens vi alle vet at en $\mathrm{ABC}$ gir en innføring (i lesekunsten); en mulighet for lærdom. Jeg trodde for øvrig at det danske alfabetet sluttet med $\AA$, og ikke Z. Skriftlig dansk skiller seg ellers fortsatt lite fra tradisjonelt bokmål.

Boken er kortfattet, og derfor litt dogmatisk, men uten store feil og mangler. Den skiller, som riktig er, mellom type 1- og type 2diabetes, som er to sykdommer med forskjellig årsak, prognose og behandling, og forskjellene i behandling og prognose er beskrevet, men ikke så tydelig. Det er mange gode og nyttige tabeller og figurer, som illustrerer viktige poeng.

Hvem er boken beregnet på? I et forord skriver George Alberti at den er spesielt egnet for leger og sykepleiere i primærhelsetjenesten - det er jeg ikke enig i. I Norge har vi nylig fått kliniske retningslinjer for helsepersonell fra Helsedirektoratet (1), og i tillegg også en egen brukerversjon. Versjonen for helsepersonell er sendt til alle leger i Norge, brukerversjonen til alle medlemmene

i Diabetesforbundet. Begge dokumentene finnes også på Internett og kan bestilles fra Diabetesforbundet av alle. Mange vil vel mene at de norske dokumentene klarer seg. For den som vil være svært bredt orientert, egner boken seg imidlertid godt som en innledning. Den er oppdatert, balansert og gir en god og kortfattet oversikt for spesielt interesserte.

\section{Jak Jervell}

Oslo

\section{Litteratur}

1. Claudi T, red. Diabetes: forebygging, diagnostikk og behandling. Oslo: Helsedirektoratet, 2009. 